\title{
Mission Policy Challenges of the Presbyterian Church of South Africa, with Reference to the New Brighton Mission Church (1897-1962)
}

Graham A Duncan

http://orcid.0rg/0000-0002-2583-1914

University of South Africa

profgrahamduncan@gmail.com

\section{Abstract}

Early in the life of settler/colonial Presbyterianism in South Africa (PCSA), congregations embarked on missions to indigenous local peoples. This was done under the supervision of White sponsoring congregations. A considerable period elapsed before any thought was given to the autonomy of these missions, and even longer before autonomy was granted. This article investigates the process and journey towards self-government in African congregations within Presbyterian polity, taking account of the racial and other issues involvedincluding power and control over Black people who found that the church was virtually the only place where they could exercise any freedom of action. The New Brighton Mission Church is an example of the problems which arose out of the lack of a clear policy.

Keywords: New Brighton Mission Church (NBMC); Ndabeni Mission; Orange River African Presbytery; Presbyterian Church of South(ern) Africa; St Andrew's congregation Cape Town

\section{Beginnings of Presbyterian Mission in Cape Town}

From the beginning of the gathering of Presbyterians in Cape Town, it was envisaged that in the "Scottish Presbyterian Church" (Bax 1997, 6) in Cape Town in 1824, there should be some form of outreach to the local population. This took place in the context of the emancipation of slaves that occurred in 1838-1840. These slaves formed a substantial proportion of the population, many of whom were Coloured. Those who originated from the East were predominantly followers of Islam and were spreading their faith freely. The minister, John Adamson, began a mission for the Khoikhoi and freed slaves. The converts had either been Muslims or "heathens." They met in a different venue from the established congregation due to having received little or no

\section{UNISA $\cong$}


education; and they worshipped in Dutch. Adamson was so committed to mission that he used his stipend to support his mission work (Quinn and Cuthbertson 1979, 23). Rev. G. W. Stegman, an assistant minister in the Lutheran congregation, was appointed to take charge of the mission assisted by the "Scottish Church" and the Dutch Reformed Churches. From 1838-1841, more than 1000 adults became members of the mission and 134 were baptised. So, the Scottish Church was the first congregation to engage in mission and open its membership to Black people and to also marry freed slaves.

Stegman started a mission school, built a school (in 1842), offered basic social services and established a "Friendly or Benefit Society ... by which members subscribing one shilling a month are supplied with medical attendance, medicines and burial" (in Quinn and Cuthbertson 1979, 17). This mission was sponsored by the "Scottish General Assembly's Committee for Foreign Missions" and other donors. A dispute between him and the next minister, George Adamson, who chose to be more active in the mission, caused Stegman to leave the congregation in 1842 with the majority of the mission to form an independent mission. A missionary association was established in 1948. In 1878 the St Andrew's mission was closed. This was a significant loss for the Presbyterians to bear and resulted in them never making a substantial inroad into the multiracial population (Bax 1997, 7). Quinn and Cuthbertson $(1979,15)$ further suggest that this actually exacerbated racial tensions. It is not clear how many of the mission groups joined the White congregation.

Besides this, in 1876, the mainly male St Andrew's Sabbath Morning Fellowship opened a mission in Bloem Street to service the African slum population of Cape Town through the ministry of an evangelist, whose stipend they paid. The nature of this mission altered through the movement of Black people out of the centre of the town. This work continued until 1893, when the Cape Town Presbytery was established. The Presbytery took responsibility for this work in 1900, and with support from various quarters, was able to pay an evangelist, Mr E. Makubalo. A year later, residents were removed to the Uitvlugt location (later to be named Ndabeni) and built a church and manse. The population was again moved to Langa and a new church was opened in 1931. This form of mission arrangement became the norm as settler/colonial Presbyterianism spread throughout South Africa.

However, there was another context in which Presbyterians carried out their witness through mission. Until 1897, it was not possible to refer to Presbyterianism as a denomination. There were congregations and presbyteries, but these lacked the authority derived from a denominational structure, which is essential to Presbyterian polity. Prior to 1897, congregations made up of Presbyterians and Congregationalists were independent units, responsible only to themselves. This resulted in an independent approach to mission and the formation of mission congregations on an individual basis because there was no superior court to supervise this development. This would become one significant factor in the delay in formulating a mission policy. 
Following the union of disparate congregations and presbyteries to form the Presbyterian Church of South Africa in 1897, a report was received in the following year that the church consisted of:

24 "European" congregations, 10 "Native" congregations, 110 mission stations, 2961

"European" and 3778 "Native" members, 3046 "European" adherents and 1394

"Native" candidates and 101 "European" and 100 "Native" elders. (Bax 1997, 11)

This explains the substantial results of mission work amongst the Black population from 1824 until 1898. However, none of the "Native" congregations had full status and remained under the supervision of White congregations.

\section{Racism in the wider South African Mission Context}

At the time of the union in 1897, the mission congregations of the United Presbyterian Church of Scotland (UPCoS) were about to unite with the Free Church of Scotland (FCoS). In 1900 the union took place and the United Free Church of Scotland (UFCoS) was formed. The UPCoS congregations became part of the PCSA. Black ministers and members were wary of becoming part of a White-dominated church. The missions of the FCoS were more cautious since they had been granted full status as they grew and developed, and they were unwilling to sacrifice their comparative liberty of operation under missionary supervision as they had their own elders and Kirk Sessions that accorded them a degree of autonomy. In this regard, Vellem $(2013,148)$ comments that this was the result of:

... ambivalence in Black faith, ipso facto, a faith distinguished by Blacks in their struggle against the ubiquitous defects of White faith and dominance right through into the post 1994 South Africa.

According to Boesak $(2009,49)$, Black people rejected what was tantamount to "an anaemic gospel of subservience and dejection - both on the blatant forms of a hundred years ago and the subtler forms of the present." The fact that the proposed supporters of one multi-racial church failed to achieve their goal of a "dissonant model of union" was "racism" due to lack of trust on the part of the Black Presbyterians (Vellem 2013, 150). This is not surprising, for the PCSA operated on the distinction between an "organic or subordinate relationship ... the Conference [a conference was held between the UFCoS, the PCSA and the Synod Kafraria of the UFCS to determine the best way forward for the Black membership] decided on the latter" to establish a Black church (PCSA 1920, 121-122). What is more problematic, is Xapile's $(1999,22)$ claim that:

The African Missions Committee of the Presbyterian Church of South Africa proposed a union of the two churches on the basis of the Book of Order of the Presbyterian Church of South Africa and particularly its chapter on Missions.

This would have made all of the congregations of an existing denomination subservient to a committee of the church it had united with, and reduced it to perpetual mission 
status. Referring to a similar context of the Swiss Mission, Maluleke (1993, 239) comments:

... the church would grow from mission stations instead of from Christian communities, that the polity of the indigenous church would be an adaptation of the mission pattern instead of growth from the needs and demands of the indigenous congregations; that the workers would be responsible for the mission of their new church; that the task of proclaiming the faith and extending the church would be regarded as belonging primarily to the mission.

So, here we see the racist emphasis, through a distinction that is racially based, of what Maluleke describes as the "Mission Colony Approach." This is similar to the main theme of Elphick's work The Equality of Believers (2012) — equality that challenged the racial discrimination, which was ubiquitous:

... the struggle over racial equalisation ... was pivotal to South African history; that this concept was rooted in the missionaries' proclamation of God's love to all people, as manifested in the birth, crucifixion and resurrection of Jesus; that the ideal of equality was nurtured in large part by missionary institutions, even though missionaries themselves repeatedly sought to limit, deflect or retard its achievements. (Elphick 2012, $7-8)$

This was in contradistinction to the policy of the Scottish Church "that the function of mission was to support new Christian communities until they could stand on their own feet and then let them go" (Davenport 1997, 67); although, in practice, the missionaries tended to settle in for the long term.

\section{A Dissenting Mission}

From the time of its formation, the PCSA held to its conviction that one united church was the best way forward for Presbyterians. The outcome of the 1920 conference was a decision that the optimum way forward would be to establish an autonomous Black church that would "develop Black leadership and an indigenous style of churchmanship, mission and evangelism" (Bax 1997, 12). When the Bantu Presbyterian Church of South Africa was formed in 1923, all of the FCoS congregations and the majority of the UPCoS became part of the BPCSA. This left the PCSA with half of its Black members, a presbytery and several congregations. The loss was almost entirely restricted to the Eastern Cape.

\section{Going it alone}

This left the PCSA to decide on the direction of their future mission work until some united arrangement could be agreed upon. Hunter $(1983,234)$ posed the alternative possibilities: "Separation, confederation or integration?" The Synod of Kafraria chose confederation, while the PCSA decided on integration. However: 
... integration meant that from its origin the PCSA had to cope with the same complex relationships that have perplexed South African society ever since, and about the interpretation of which historians disagree according to their ideology. (Hunter 1983, 234)

Hunter notes that the context for mission had changed significantly by the end of the nineteenth century. What had been a rural operation was now confronted with mass migration to developing urban centres and the opportunities that this presented to both the Synod of Kafraria, which could not cope with the developments in the urban areas, and for the PCSA. This forced the PCSA to adapt "from [being] a church that talked about mission to a church actively involved in mission" (Hunter 1983, 236).

It became the pattern that "African mission work went hand in hand with the formation of White congregations" (Hunter 1983, 9). However, here the race issue was ubiquitous. During a crisis in the Johannesburg congregation, the Synod of Kafraria resolved:

Owing to the variety of races and tribal jealousies and especially owing to the harsh treatment of natives at [in] Johannesburg, the disabilities under which the native minister labours because of that treatment, the work there will be carried on most efficiently and satisfactorily by a European missionary ... (Synod of Kafraria 1897, 353)

The response of Rev. J. D. Don, clerk to the Synod of Kafraria, is instructive:

... we cannot afford to act upon the assumption that the native is really equal to the European.... I have been notoriously a friend, if you will, but have sorrowfully modified some of my earlier ideas owing to larger experience and more intimate knowledge. They are at their best as assistants or as ministers working under the surveillance of Europeans. (Synod of Kafraria 1898)

This is a devastating indictment of mission policy up to the formation of the PCSA, especially regarding the use of the term "surveillance" with its sinister negative connotations. Don appeared to be advocating subservience on the part of Black ministers. Yet, there were only a small number of rural dispersed mission congregations, so the PCSA could hardly claim to be a church engaged in mission.

At the second General Assembly of the PCSA in 1897, Rev. John Smith highlighted the need for the denomination to alter its attitude to mission work if it was to be faithful in urban mission (Presbyterian Church of South Africa [PCSA] Blue Book [BB] 1898, 55). For this, the Scottish model was inadequate:

It is not with us a Foreign Mission: it is in reality a Home Mission, and as such is not to be relegated to a secondary place in our sympathy or our councils, our gifts or our prayers. (PCSA BB 1898, 106)

The close relationship between urban mission and White congregations, where African missions would be seen as extension work, was viewed as local mission, although that 
never became a reality for the connecting link tended to be in the form of financial support rather than the development of close relationships. The inability of the PCSA to move from the "foreign" to the "home" approach to mission was compounded by several factors. First, the Assembly made a decision to separate the work of mission. A Church Extension and Aid Committee were formed to embark on mission in the White areas, while the Native Mission Committee would be responsible for mission to Africans (PCSA BB 1897, 16-17). In 1958, additional separate committees were formed to pursue mission among the Coloured and Indian populations (PCSA BB 1958, 48). It is difficult to understand the rationale behind this decision that lasted until 1960, which meant that a change in mission policy was long delayed. This decision indicated:

... public recognition that over the years the church has grown in strength and stability by the addition of many African members, and that our relationships within the church are no longer that of missionary to convert but that of fellow members in equal standing. (PCSA BB 1960, 59)

Second, the African Mission Committee had no authority to impose a consistent mission policy throughout the African mission context, indicating that local control was favoured over centralisation that had been on the agenda of the General Assembly since 1906 (PCSA BB 1906, 139-140). Third, while White congregations proceeded towards recognition as full status charges, no clear guidelines were formulated for African congregations to achieve full status, leaving them under perpetual White trusteeship. All of this indicated that there was no substantial agreement within the PCSA regarding a strategy for mission and no immediate prospect of African congregations attaining their majority. This appeared to indicate that the PCSA was actually a congregational, rather than a presbyterian, church that operated without a clear denominational approach to mission.

This was highlighted from an early stage in the life of the PCSA. In 1908, Rev. J. J. McLure, Convener of the AMC, challenged the General Assembly:

Unless the Assembly is prepared to face further chaos, and condone direct disregard of Assembly's resolutions as well as to save the future of the church's mission work it will be necessary for the Assembly to direct the attention of the members and office-bearers of the church to our mission work as a whole. (PCSA BB 1908, 145-146)

Here McLure was referring largely to the financial support of missions that appeared to be the main function of the AMC. However, presbyteries soon sought devolution of this responsibility, which was granted in 1922. However, things were somewhat different on the ground with regard to the growth and development of mission congregations, as can be seen from the example of the New Brighton Presbyterian Mission Church. 


\section{The New Brighton Presbyterian Mission Church as an Example of an Unclear Mission Policy}

The origins of the New Brighton Presbyterian Mission Church (NBMC) are to be found in the desire of members of the Hill Presbyterian Church in Port Elizabeth, from 1904, to assume responsibility for the spiritual care of the growing African population "the native Christians coming from the Stations to the towns" (PCSA BB 1898, 55). These had been members from the Synod of Kafraria, which agreed to transfer them to the PCSA without prior consultation. Yet, the delay in transfer-due to the ongoing discussion of the union of mission presbyteries and synod-had a negative effect on the development of the NBMC. By 1905, the Hill had already been responsible for the birthing of the South and North End congregations of White members. The NBMC faced an early threat from the upsurge of activity stimulated by the Ethiopian movement, which was an expression of resistance to the type of mission Christianity pursued by the Churches of European Origin (CEOs). To assist the Hill congregation in avoiding losing its mission, the Free Church Presbytery of Kafraria sent a probationer, Petrus Matshikwe, to assist in the congregation temporarily. As the result of Matshikwe's faithful ministry, the Presbytery of Kafraria established a Session and Deacon's Court in November 1899, and two elders and a deacon were ordained to their respective offices of ministry in 1900 (Christian Express [CE] XXIX, December 1899, 189; CE XXX, November 1900, 168). However, in Hunter's $(1983,30)$ account, there is no mention of Matshikwe being ordained to the ministry of word and sacrament. This was one of the long-term grievances of those who formed the Ethiopian movement and led to secessions. The problem was the attitude of many White members that remained inherently racist and not conducive to strong bonding fellowship.

The Kafrarian Mission Council had a change of heart in 1910 and requested the Presbyteries of Adelaide and King William's Town to take responsibility for its African work in Port Elizabeth and East London (Presbytery of Adelaide Minutes 17 May 1911).

During the early years of the PCSA, White congregations' concern for the spiritual welfare of their rural members who were moving into urban areas, led to greater commitment to caring for them. Consequently, the Synod of Kafraria was more inclined to transfer its members to their care. This was the case in Port Elizabeth. However, referring to the case of the New Brighton Mission Congregation and the Hill Presbyterian Church in Port Elizabeth, Hunter's $(1983,20)$ assessment of the PCSA's performance in mission was that "in experience and in opportunity it was a continent apart." Yet, embarking on this mission, in some small way, testified to the PCSA being involved in mission as part of the church catholic. The Presbytery of Adelaide took full responsibility for the New Brighton congregation and thereby established a model that became the norm-a Black minister "in charge" of the mission, working under the "surveillance" of a White mission committee. While it did provide opportunities for cooperation and fellowship between Black and White, it remained a tool of oversight and supervision. Despite this, at a time of growing segregation, most of the missionary 
outreach was done by Black people themselves. An editorial in the Christian Express (XXXIII, April 1903, 97) summed up the Black person's view of this type of arrangement:

But so long as the Native minister or elder is only a "boy" to the White elder-a "boy" with whom it is not "good form" to shake hands or invite into your pew in church, there may be a legal bond but there can hardly be a true union.

Then questions were raised concerning the membership of Black people in White congregations and their admission to the Lord's table. The issues here referred to a lack of authenticity in relationships.

The first Black minister, Jarvis Gqamlana, ordained to the ministry and inducted as minister of the congregation on 9 July 1916, focused on the mission as a "comfort station" where new arrivals in Port Elizabeth could find, in the trauma of urban life, fellowship and community in worship, prayer meetings and in the Women's Association, Girls' Auxiliary and Young Men's Association, all with their emphasis on evangelisation. This mission soon established its own mission in Vlei Post. Other preaching stations were added at Addo (PCSA BB 1927, 145), Salisbury Park and Uitenhage (PCSA BB 1931, 728).

Gqamlana developed educational pursuits in order to provide skills to negotiate entry into urban life. Foremost among the problems faced was having to live in reduced space with no infrastructure and land to grow food. Alcohol abuse became endemic and crime was rife. It was little wonder that movements in support of total abstinence became a significant means of outreach. Then the Black population had to endure the effect of the new Union of South Africa's (1910) liquor policy, the Natives Land Act, 1913, the influenza epidemic in 1918, the Natives (Urban Areas) Act (1923) as well as insanitary living conditions. A succession of ministers eschewed political involvement as a means of mission in a racially intensifying situation, despite their commitment to social justice through education and temperance. They had sought a mediating role between Black and White. In all this, the New Brighton Church courts had a degree of self-government.

Comity problems arose when Rev. G. G. Miza from the Bantu Presbyterian Church (BPC) arrived in Uitenhage to minister to his members from Somerset East, who had moved there for work. This led to constant tension between the PCSA and BPC in this and other congregations in urban areas. These tensions were exacerbated when BPC congregations began to seek to return to the care of the PCSA. Among the reasons given were lack of pastoral care and regular access to the sacraments. This was due, in part at least, to the financial insecurity BPC ministers experienced as they had no supportive White congregations to pay deficits in their stipends. Consequently:

There has been a falling away in the much needed work of evangelism among the heathen, and the present Christian community is not being adequately conserved. The 
systematic visitation by ministers and elders of homes in the district is a thing almost unknown. (Lennox Memorandum 1928, 3)

This was because some had to resort to "... anything from teaching and freelance journalism to farming, running a butchery, insurance agency etc." This highlighted the differences in mission policies and their outcomes (Lennox Memorandum 1928, 4). Clearly, the PCSA (PCSA BB 1937, 134) General Assembly in 1937 concluded: "constantly increasing trouble must take place between two churches, essentially one, yet holding policies so diametrically opposed."

Gqamlana died suddenly in 1932. Yet the NBMC had ministers who were well able to provide leadership at the national level and did so. Rev. J. J. R. Jolobe was the first Black Moderator of General Assembly in 1976. Rev. G. B. Molefe was the first Black Moderator of a Presbytery (1973-1974). Rev. L. S. L. Mateza was elected Moderator of General Assembly (1983-1984). Jolobe and Molefe, both former ministers of the BPC, were teachers. They played significant roles in the development of African education; they were respected community leaders and were at the forefront of promoting Black leadership in the PCSA and both had a strong reconciling spirit, and they eschewed direct political engagement. They both favoured change, but within the structures of the Presbyterian system of polity. Jolobe was inducted to NBMC in 1933 and Molefe to the same position in 1939.

While denominational parish boundaries were respected in rural areas for the most part, "comity was destroyed and denominational rivalry abounded" in the urban districts (Hunter 1983, 94). An important factor was the BPCSA decision to follow its members into these urban townships. This led to a deterioration of relationships between the two Presbyterian denominations and led the PCSA to call for a speedy organic union in order to "maintain and develop their common Presbyterian heritage for the greater glory of God" (PCSA BB 1935, 34). However, the BPCSA demolished any attempt to bring about such a union. Paterson (Letter to Shepherd, 7 November 1935, Cory MS 16460) of the PCSA commented:

What I fear is the isolation of the Bantu Church from all European influence. And I fear the consequences of that for them and for ourselves. And I believe that the first duty laid upon our church is to win the native people of this land into a sense of brotherhood-a brotherhood completely unrestricted by any sense of peddling little notions and conventions which have, unhappily, invaded our very churches.

What, to Paterson and his PCSA colleagues, were "peddling little notions and conventions" was a blatant euphemism for racism. In reply, Shepherd referred to the "goodwill and cooperation" that had been rejected. He clearly did not realise the racist dimension of Paterson's comments. This was a considerable setback for progress towards union and to a developing mission policy. Jolobe proposed that two things were necessary to improve the situation. First, it was necessary to train an African ministry that would be able to minister to a population that was becoming increasingly educated. 
Second, there was a need for the church to become more engaged in African education. Consequent to this was a need to raise the standard of theological education by moving to the South African Native College (PCSA BB 1922, 30, 40; Kerr 1968, 56). This situation was caused by an inadequate ministry in terms of numbers and qualifications:

It would be a very great help to us to get some ideas how these teachers could be instructed to cope with the present learned generation in order that they may fill up both young and old members evenly with spiritual teaching. Many teachers we have are inferior to their church members in knowledge. (PCSA BB 1935, 120)

For Jolobe, a well-trained ministry was vital for faithful mission work. Consideration was given to the use of evangelists and lay preachers to assist in meeting the deficit in ministry numbers. Two years' training was prescribed and negotiations took place with the Lovedale Bible School (PCSA BB 1936, 110), where it was agreed to train lay preachers. In 1937, it was agreed that ministers and evangelists would undergo a twoyear training (PCSA 1937, 118, 121).

In 1937 and 1944 respectively, Jolobe and Molefe left full-time ministry to pursue careers in education. Both had done well in the congregation at NBMC (Hunter 1983, 118), but both had a wider vision of mission, which led them to full time careers in education. But there may have been other motives at work. They had achieved little with regard to changing the status of the NBMC, despite their efforts to promote the Christian witness of the congregation. It is possible that they had adopted a stance of "subversive subservience" (De Kock 1996, 140) in order for the NBMC to survive, if not thrive.

African public expression ostensibly showed respect for imperial values, but in fact confronted the colonial world with the supplementary incongruities of those values in the deferred South African context [which] depended on a stable presence of "civilisation." But there was no undoing the ambivalences of colonial identity. Thus, the paradox that when Africans adopted missionary discourse and used it to fight for the equality implicit in the promise of "civilisation," "civilisation" itself proved to be the most ambivalent signifier of all.

NBMC had been active in mission and had benefited from the ingoing financial support from the three White congregations in Port Elizabeth and the substantial number of lay preachers available to assist in mission.

Rev. W. M. T. Ntintili was inducted into the NBMC in 1946. He adopted a different perspective as he viewed the situation in terms of White domination. He took the view that the congregation's existence was threatened by the presence of the NBMC. His views were clearly subversive and led to division in the congregation when he advocated the separation of the congregation from the mission, that is, from White control. Ntintili was not prepared to be dominated and, consequently, faced divided courts within his congregation that disturbed the "peace and unity" of the church through a threat to its relationship with the White congregations in Port Elizabeth. Without this support their 
financial viability was at risk. This indicated that far from integration being achieved, White domination persisted in the context of a striving after a degree of autonomy. This was clear from the absence of processes for Black members to rise to positions of leadership in the denomination. The outcome of this situation was an emphasis on the lack of a defined mission policy in the PCSA.

\section{The Orange River African Presbytery}

A further anomaly arose due to the existence of mission congregations in urban areas and African congregations in the Orange Free State, which had been formed into the Orange River African Presbytery in 1921 to accommodate congregations that were under African ministers separate from the White congregations. These congregations were to be found at Heilbron, Reitz, Diamond Fields, Lindley and Kroonstad. This arrangement, which accorded some autonomy to African congregations, that was different from integration, indicated that not all mission congregations were at the same stage of development. However, the situation was not at all clear.

In 1943, the Orange River Presbytery sought the Assembly's guidance on African ministers' status in the presbytery (PCSA BB 1942, 112). They were reminded that in 1921, Assembly had ruled that African ministers were placed as assistant ministers (PCSA BB 1921, 31-32). Despite this, the presbytery had sanctioned the call of African ministers. This was the procedure in other presbyteries. A commission was established to consider the matter. The commission agreed that the only ministers who could be recognised were those who had undergone the prescribed training or were suitably qualified. They further asserted that congregations were required to be financially stable and able to pay their ministers. Then the White elders, who had been appointed to attend presbytery meetings, would continue to do so. Jolobe pointed out that the PCSA would have to respond to the demand for equal rights of all members in congregations without consideration of race:

This question threatens to become a major issue in the life and thought of the African people in the churches, and I think it will ultimately be one of the fundamental tests of the unity of the church in this country. I must say, however, that Africans are not demanding social equality but they expect and are beginning to ask for equality in religion and of equality of opportunity in the political spheres. (PCSA BB 1943, 73)

There was little significant action until the Ntintili matter in New Brighton erupted, again forcing the matter of mission policy onto the agenda of the General Assembly. The question of the status of NBMC came into public view for the first time. This was an ongoing dispute that highlighted the need for a consistent mission policy. Without going into the details of the dispute (see Hunter 1983, 128-182), this case revealed the chaotic state arising out of there being no clear mission policy in the PCSA. 


\section{The Struggle for a Mission Policy}

The AMC had attempted to resolve the issue of differentials in congregational development at the 1915 General Assembly. While it was agreed that the formation of an African church was the ultimate ideal, it was also felt that in a time of rapid change in South African society, this was not an appropriate juncture at which an established policy was either desirable or even possible (PCSA BB 1915, 191). However, racial overtones persisted since it was agreed that while Africans would be the main agents of evangelism, White guidance would still be necessary in the fields of doctrine and polity:

We cannot expect that our methods of organisation and work will be copied in their entirety by them. The methods of the Native church will evolve spontaneously out of its own sense of adaptation to its environment. Its interpretation of Christ will reflect its distinctive racial thought and feeling. Errors and lapses will no doubt retard its growth, just as they have retarded ours. But under the guidance of the Holy Spirit inconsistencies and excrescences will fall away, and only its true contribution to the sum total of Christian faith and experience will remain. (PCSA 1915, 192)

This presents a good example of the semper reformanda principle at work. However, it is hardly conceivable that such developments would be tolerated in a White-dominated denomination. Despite regular affirmations of the wisdom of raising African congregations to full status, the PCSA constantly failed to develop a process by which this could happen. The 1933 General Assembly view of mission policy was that it must focus on the "broad, deep current of life [that] is allowed to move on" and discern "what designs He has for the Native peoples who laid down His life for them as well as for us and Who is not ashamed to call them brethren" (PCSA BB 1933, 103). This lacked clarity and substance.

In 1938, the General Assembly AMC again raised the necessity of a mission policy that could be applied throughout the denomination. In this regard, a number of questions had to be addressed. First, would congregations work towards integral cooperation or separate development? Second, separate church courts would be needed so African issues could be addressed since the General Assembly, it was agreed, was not the appropriate court for this. Third, there would need to be an effort to increase the number of African ministers. Fourth, to accommodate an increase in the number of ministers there would need to be a substantial increase in income (PCSA BB 1938, 139). These proposals were referred back to the committee. No further action was taken for several years.

After a fractious presbytery case in which the pastoral tie between Ntintili and his New Brighton congregation was dissolved, Rev. Ntintili left a seriously damaged NBMC on 9 March 1949; yet he was a catalyst for action. During the previous year the General Assembly had appointed a special committee: 
... to explore the whole question of African mission policy of our church, the desirability of making fuller provision in the Book of Common Order for the possibility of closer relationships with the Bantu Presbyterian Church for the carrying out of that policy. (PCSA BB 1948, 87)

The report of the committee stated:

Our African brethren will readily appreciate the justice of one law, which demands the same high standards for all members, irrespective of race; but they will inevitably nurse a sense of great injustice if we, at this late stage, without the most careful deliberation repudiate the status which they, in all good faith and relying upon our good judgement, believed that they have received from us. (PCSA BB 1950, 86-87)

The Assembly then appointed a commission to:

... investigate thoroughly the constitutional position of the mission stations which have been referred to, or treated in any measure, as congregations, and to submit its recommendations with reasons for the clarification of their constitutional position and the declaration of their status. (PCSA BB 1950, 34)

The main subjects of the commission's work were the New Brighton congregation and the Presbytery of the Orange River. With regard to New Brighton, it was agreed that this was a mission congregation; its session was at the third stage of preparation for full status, while the Deacon's Court was only at the first stage. With regard to the Orange River situation, it was noted that it was already the policy of the PCSA that White and Black people should have full equality in church courts and subsequently, White and African presbyteries should be united. However, the status quo would remain until this could become a reality. Yet, no indication was given regarding how or when this would be achieved. However, in 1954:

The Assembly instructs the Presbyteries of the Orange River, African and European to unite: and to delimit the area of the present African Churches in such a way that the districts not readily served from any existing centre may fall under the care of a Mission Committee of the united Presbytery. (PCSA BB 1954, 73)

The result of this decision was that the African presbytery was no longer independent, which ended the anomaly in a Presbyterian system and also in the racial situation.

Then, the commission was instructed to:

Prepare a set of rules for the establishment, organisation, maintenance and administration of mission stations, such rules to be so framed as to guide and aid in the training of members of mission stations to qualify those stations for recognition by General Assembly as fully sanctioned charges. (PCSA BB 1951, 90) 
The resulting schema included three stages of development; first, the preaching place, which was experimental and temporary; second, the outstation or preaching station, which was under the supervision of an existing session or mission session that was a probationary stage with financial aid required; and third, the mission congregation. When the stage of stability of finance and administration was reached, such congregations could apply to the General Assembly to be raised to fully sanctioned charges.

Presbytery AMC responsibilities were also defined. These included establishing, coordinating, regulating and extending evangelistic and educational work within presbytery bounds. In addition, presbyteries were to take responsibility for appointing those involved in mission work and the administration of all funds, report to General Assembly and submit budgets, cooperate in the selection of suitable candidates for the ministry, ensure they had vacation work placements and recommend the granting of full status, which conferred the same rights, responsibilities and privileges as White congregations. Mission congregations had no right to call ministers. In the absence of a minister, Presbytery would appoint an ordained missionary or White minister as interim moderator.

The Assembly AMC was also given clear responsibilities: to administer funds allocated to African Missions; provide literature for presbytery mission committees; and supervise the training and appointment of African students and evangelists. This delineation of powers and responsibilities ensured that the White members of the PCSA were clear about their responsibilities for authentic mission rather than domination expressed through supervision or "surveillance."

During this period, the policy of apartheid had been implemented and was being consolidated. The Moderator of the General Assembly in 1949, Rt Rev. John McDowall, made it clear that segregation was not just a product of the political system but: "Verily, the true 'apartheid' is in the soul of man" (PCSA BB 1949, in hunc effectum meeting, 33). Thus, it was a spiritual matter and, therefore, very much the business of the church and its members, many of whom adhered to the notion that church and politics do not mix. Hunter $(1983,190)$ makes a perceptive comment in this regard: "This basic misunderstanding or underestimation of the gospel's power to create a new order in human affairs has led to a considerable gap between the PCSA Assembly's resolutions, and congregational resolve and action." However, she fails to mention that this is not true of the African population in the church. It was easy to pass resolutions, but implementing them was extremely problematic (cf. Bax 1997, 22), particularly the command to love, with all its implications, even within the same denomination. In response to the Cottesloe Declaration:

The PCSA had thus discovered that before it could proclaim Christ's offer of reconciliation to a divided nation, it needed to appropriate Christ's forgiveness for its own racism, and to re-discover Christ's reconciliation within its own courts and congregations. (Hunter 1983, 198) 


\section{Full Status}

On 11 October 1960, the Presbytery of Adelaide considered that the NBMC was close to meeting the requirements for full status. It had met all of the requirements stated in the Presbyterian Church of Southern Africa Book of Order (1960, § 206, 44). The NBMC submitted an application to be raised to full status in July 1962 to the Presbytery. It had 414 members and 160 adherents. Its courts were operating well and it had been self-supporting financially for a number of years. The Presbytery approved the application and transmitted it to the General Assembly. The Assembly approved the application on 14 September 1962 (PCSA BB 1962, 230). This enabled the congregation to call its own minister, which it did, and Rev. J. J. R. Jolobe was inducted into the charge on 20 October 1962. This was the first African congregation to achieve full status 65 years after the formation of the PCSA. This marked the end of an almost interminable process towards a mission policy that recognised the full humanity of its African members.

\section{Conclusion}

The PCSA found it was problematic to translate biblical principles such as "unity in fellowship" into practice. They "found it easier to remain the prisoner of history, culture and tradition, rather than the hope of the new order that lies at the heart of the gospel" (Hunter 1983, 245).

The path from dependence to independence for mission congregations of the PCSA was somewhat convoluted and lengthy. This was, in part, due to the absence of a definitive form of Presbyterian polity to govern policy development and implementation. St Andrew's congregation in Cape Town developed a proto-type for a mission congregation, which was in time, as Presbyterianism migrated throughout southern Africa, replicated throughout congregations and presbyteries, which formed the PCSA in 1897 and beyond as the PCSA became a transnational denomination. The early situation was understandable, while there was no denomination to take overall responsibility for mission, but that changed radically in 1897 . Despite its affirmations to the contrary when it was founded in 1897, the PCSA had not developed a clear understanding of what it meant to be a missionary church and, consequently, its approach to mission was reactive rather than proactive. The spirit of independency provided an enduring legacy in terms of mission outreach.

Although it was hardly mentioned overtly, the issue of racism (Duncan 2018, 37-38) was ubiquitous, acting as a restraint on precipitate action. It might be concluded that mission congregations enjoyed the "comfort" of not having to be financially responsible while there was a neighbouring sponsoring White congregation to pay the bills. They were prepared to sacrifice control of their own affairs for financial security, arising out of the beneficence of White congregations, to the placing of trust in Black ministers. They benefited from these arrangements, especially when they offered protection from the political and religious threat that came from Ethiopian-type churches. On the other 
hand, it is possible that White congregations enjoyed their charitable role with regard to their missions and the possibility that the relationships this engendered of going against the grain of history by apparently crossing racial boundaries. However, there is no evidence that these have had a long-term positive effect. White congregations did not need to occupy a supervisory role in order to offer support to mission congregations. Perhaps a more straightforward explanation is that the status quo is comfortable, while change implies risk. The decision to adopt a progressive approach towards achieving full status provided mission congregations with the impetus to work towards autonomy within the Presbyterian system of polity.

\section{References}

Bax, D. S. 1997. The Presbyterian Church of Southern Africa. Cape Town: D Bax.

Boesak, A. 2009. Running with Horses: Reflections of an Accidental Politician. Cape Town: Joho Publishers.

Christian Express. CE] XXIX, December 1899, 189. Lovedale: Lovedale Press.

Christian Express [CE] XXX, November 1900, 168. Lovedale: Lovedale Press.

Christian Express [CE] XXXIII, April 1903, 97. Lovedale: Lovedale Press.

Davenport, R. 1997. "Settlement, Conquest and Theological Controversy: The Churches of Nineteenth Century European Immigrants." In Christianity in South Africa: A political, Social and Cultural History, edited by Richard Elphick and Rodney Davenport. Claremont: David Philip, 51-67.

De Kock, L. 1996. Civilising Barbarians: Missionary Narrative and African Textual Response in Nineteenth Century South Africa. Witwatersrand University Press

Duncan, G. A. 2018. "To Unite or not to Unite? That is the Question: A Case Study of Presbyterianism in South Africa, 1897-1923.” DOI: ISSN 1015-8758 (Print) ISSN 23099089 (Online) Acta Theologica 38 (1): 37-60. https://doi.org/10.18820/23099089/actat.v38i1.3.

Elphick, R. 2012. The Equality of Believers: Protestant Missionaries and the Racial Politics of South Africa. Pietermaritzburg: University of KwaZulu-Natal Press.

Hunter, C. F. D. 1983. "Some Aspects of the African Mission Policy of the Presbytery of Adelaide/Port Elizabeth with special Reference to the Origin and Development of the New Brighton Presbyterian Mission Church 1898-1962." PhD thesis. Grahamstown: Rhodes University.

Kerr, A. 1968. Fort Hare, 1915-1948: The Evolution of an African College. Pietermaritzburg: Shuter \& Shooter. 
Lennox, J. 1928. Memorandum, 31 May. Johannesburg, William Cullen Library, University of the Witwatersrand.

Maluleke, T. S. 1993. "Mission, Ethnicity and Homeland: The Case of the EPC". Missionalia 21 (2 November): 236-252.

Paterson, H. M. 1935. "Letter to R. H. W. Shepherd,” 7 November 1935, MS 16460. Cory Library for Historical Research. Grahamstown: Rhodes University.

Presbyterian Church of Southern Africa Blue Book (PCSA BB) 1897, 1898, 1908, 1915, 1920, 1921, 1922, 1927, 1931, 1933, 1935, 1936, 1937, 1938, 1942, 1943, 1948, 1949, 1950, 1951, 1954, 1958, 1960, 1962. Proceedings of the twenty-third General Assembly. Johannesburg: PCSA.

Presbyterian Church of Southern Africa 1960. The Book of Order of the Presbyterian Church of South Africa. Johannesburg: PCSA.

Presbytery of Adelaide Minutes, 1911.

Quinn F., and G. Cuthbertson. 1979. Presbyterianism in Cape Town: A History of St Andrew's Church, 1829-1979. Cape Town: St Andrew's Presbyterian Church.

Synod of Kafraria 1897. Minutes, MS7798, Edinburgh: National Library of Scotland:353.

Synod of Kafraria 1898. Letter Don to Lindsay 24 January, MS7798, Edinburgh: National Library of Scotland.

Vellem, V. S. 2013. "The 'Native Experiment': The Formation of the Bantu Presbyterian Church and the Defects of Faith: Transplanted on African Soil." Missionalia 42 (3, August 2013): 146-163. https://doi.org/10.7832/41-2-11.

Xapile, S. P. 1999. "The Question of Unity between the Bantu Presbyterian Church of South Africa and the Presbyterian Church of Southern Africa, 1958-1973." DTh thesis. Stellenbosch: University of Stellenbosch. 